Cumhuriyet International Journal of Education-CIJE

e-ISSN: 2147-1606

Vol 5 (3), 2016, $48-66$

\title{
Teacher Candidates' Learning Strategies and Academic Self-Efficacy Levels: Is There a Relation Between the Two?
}

\author{
Mustafa Öztürk AKÇAOĞLU1
}

\begin{abstract}
The current study aimed to identify teacher candidates' learning strategies and academic selfefficacy levels. Furthermore, the correlations between these variables and gender and departments were looked into. The study was mainly descriptive and correlational. The sample of the study consisted of 256 teacher candidates enrolled at a faculty of education. To collect data, The Motivated Strategies for Learning Questionnaire (MSLQ) and Academic SelfEfficacy Scale were used. During the analysis phase of the study besides descriptive statistics, bivariate correlation and multivariate analysis of variance were carried out. The findings revealed that there was a significant correlation between the learning strategies rehearsal, organization, metacognitive self-regulation, association, time/study environmental, and peer learning and help seeking. The results MANOVA revealed significant relations between rehearsal, organization, metacognitive self-regulation strategies and departments and gender. Furthermore, the findings indicated that the teacher candidates had an overall high academic self-efficacy levels.
\end{abstract}

Key Words: Learning strategies, academic self-efficacy, gender, teacher candidates.

Özet

Bu çalışmada öğretmen adaylarının öğrenme stratejileri ve akademik öz-yeterlik düzeylerinin belirlenmesi amaçlanmıştır. Ayrıca, bu iki değişken ile birlikte cinsiyet ve bölüm değişkenleri arasındaki ilişki araştırılmıştır. Çalışmaya 256 öğretmen adayı katılmıştır. Veri toplama aracı olarak Öğrenme Stratejileri Ölçeği ve Akademik Öz-yeterlik Ölçeği kullanılmıştır. Verilerin analizi sürecinde betimsel istatistik yöntemlerine ek olarak iki değişkenli korelasyon ve çok değişkenli varyans analizi gerçekleştirilmiştir. Araştırma bulguları, öğrenme stratejileri yineleme, düzenleme, metabilişsel düzenleme; ilişkilendirme, zaman ve çalışma ortamı ve akran işbirliği ve yardım isteme, arasında anlamı ilişki olduğunu ortaya koymuştur. MANOVA sonuçları ise tekrar, düzenleme, metabilişsel düzenleme ve katılımcıların bölümleri ve cinsiyet değişkeni arasında anlamlı bir ilişki olduğunu ortaya koymuştur. Buna ek olarak, araştırma sonuçları öğretmen adaylarının yüksek düzeyde akademik özyeterlik düzeyine sahip olduğunu göstermiştir.

Anahtar Kelimeler: Öğrenme stratejileri, akademik öz-yeterlik, cinsiyet, öğretmen adayı.

\section{INTRODUCTION}

In the $21^{\text {st }}$ century, information has become an important asset. In this regard, the characteristics of a well-educated individual include adapting to the improvements, accessing information easily, creating and using new information, thinking critically and acquiring learning strategies through education (Açıkgöz, 2005). In order to educate the students to meet the above mentioned requirements, the education process has to be examined and, if needed, revised swiftly and carefully. Because students, in this century, are called "digital natives" and they "think and process information fundamentally differently from their predecessors" (Prensky, 2010, p. 1). Prensky (2010) also implies that the changing thing about our students is not their capabilities but their needs and endurance. This change in the students' characteristics has ended up with the need to adopt innovative methods for teaching (Roehl, Reddy, \& Shannon, 2013, p. 45).

${ }^{1}$ Okt., Kastamonu Üniversitesi, Eğitim Fakültesi, ozturk@kastamonu.edu.tr 
Cumhuriyet International Journal of Education-CIJE

e-ISSN: 2147-1606

Vol 5 (3), 2016, 48 - 66

According to Weinstein and Mayer (1986), a good education, encompasses teaching the students how to learn, remember, think and motivate themselves. However, the students, at one point in their school life, experience the feeling of inability to learn regarding a specific course or all the courses. Furthermore, they mostly encounter and state the difficulties they face while learning. Some express their frustration by implying that although they try hard to success they fail and some others feel stressed because of spending too much time to learn. The rising number of issues related to the learning difficulties makes the decision makers recognize the significance of self-regulating and active participant students. Within this framework, the importance of such differences as intelligence, abilities, learning styles, learning strategies, perceptions, epistemological beliefs and self-efficacy during the designing process of curricula have to be considered (Bal, 2013). Because the success of the students, to a great extent, depends on their awareness regarding their capabilities and learning strategies (Şahin \& Çakar, 2011). To this end, many countries make changes related to their education policies and educational institutions focus on educating individuals who can access and produce information rather than consuming the information load presented for him or her. In addition, countries try hard to make their students recognize the ways they learn, have the ability to monitor their learning and select and use strategies that direct them to academic success.

In this process, "learning how to learn" has become an important concept which can be accomplished by teaching the learners "learning strategies". Learning strategies can be defined as "the techniques or skills that an individual selects in order to accomplish a learning task. They differ from learning styles in that they are techniques rather than stable traits and they are selected for a specific task"(Grigerenko \& Sternberg, 1995, pp. 7-8). Students, as active participants, utilize some type of learning strategies during the learning process. Depending on the student, the choice of a strategy can sometimes be a conscious one and sometimes it is an unconscious choice. In making such a choice, although the means change, the aimed result, as also stated by Chamot (2004), is the learners' desire to accomplish a learning goal. Furthermore, students often use several learning strategies to increase the depth of their knowledge, answer the demands of the learning environment and improve the quality of their course results (Samms \& Friedel, 2012).

Therefore, teaching these strategies and having students who are aware of their learning process are very crucial and have to be initiated at an early age. These strategies will also help a students learn on their own and improve their academic success. In addition, each learning strategy can be regarded as a facilitator for a good learning (C. E. Weinstein \& Mayer, 1986) and these strategies will assist the students to find solutions to the problems encountered in their lifetime (Hamurcu, 2002).

Despite being a crucial factor in academic success, the learning strategies are not the sole indicators of such important concepts as problem solving, accessing and using information or being a successful member of a society. In order to improve the quality of education, the importance of the student's self-evaluation along with other social skills has to be considered. Thus, self-efficacy, namely academic self-efficacy, comes to the fore as a significant factor to focus on. Academic self-efficacy is the confidence shown by the individuals in their skills to accomplish academic tasks at the desired level (Schunk, 1991). The students with higher academic self-efficacy try harder and show greater persistence to handle a given academic task because they are better prepared to overcome such demanding situations. Moreover, it is asserted that if the students have high academic self-efficacy, they may become better learners in terms of using effective cognitive strategies in learning, managing their time and learning environments more effectively, and being better at monitoring and regulating their own effort (Chemers, Hu, \& Garcia, 2001). Therefore, it can be stated that teaching students how to use learning strategies, making them 
Cumhuriyet International Journal of Education-CIJE

e-ISSN: 2147-1606

Vol 5 (3), 2016, 48 - 66

aware of their capacity and showing them the effect of academic self-efficacy on their achievement is of great significance. Because of this, as aimed in this study, detecting the awareness of teacher candidates in terms of learning strategies and academic self-efficacy can be an initial step towards the integration of these two crucial concepts into the curricula. Furthermore, this awareness should be raised at an early stage so that the teacher candidates can notice that teaching through route memorization is far from being sufficient to train students who can access and interpret information. To shed a light on the current situation, the following research questions were investigated;

1. Is there a relationship between teacher candidates' level of academic self-efficacy and the learning strategies they utilized?

2. What are the learning strategies the teacher candidates' use?

3. What is the level of teacher candidates' academic self-efficacy?

4. Is there a relationship between the learning strategies utilized and academic self-efficacy levels of teacher candidates enrolled at the faculty of education with regard to gender and departments?

\section{REVIEW OF LITERATURE}

"What people think, believe, and feel affects how they behave" (Bandura, 1986, p.25).

The difficulties related to the teaching process in the $21^{\text {st }}$ century brought about a shift in the roles of teachers and students. The students have become the active participants and are responsible for their own learning and the teachers act as guides in this learning process. In addition, the individuals are required to access, interpret, criticize and use the information. In order to acquire such features, the learners are to be taught the concepts related to learning strategies.

Commander and Smith (1995) defined learning strategies as the cognitive activities that affect the academic success of the students at all levels and keep students focused in order to understand and remember the information. Carns and Carns (1991) explained these strategies as individuals' learning styles and choices which improve their cognitive control along with their academic success. In addition to these definitions, C. E Weinstein and Mayer $(1983$, p. 2) define learning strategies as "behaviours and thoughts in which a learner engages and which are intended to influence the learners encoding process". In this process, students apply different efforts because they have different potentials and different ways of learning. Therefore, understanding the individuals' differences regarding the strategies is crucial since these shape the instruction style of a teacher. Furthermore, comprehending the learning strategies utilized by students can contribute to teachers' efforts in teaching and learning process (Mattarima \& Hamdam, 2011). For this reason, finding out which learning strategies the students use and stating the relation the strategies have with other constructs can be a step towards better learning and teaching.

A number of taxonomies regarding the learning strategies were proposed. Some researchers classified the learning strategies according to the places they are used, yet some others classified them based on the contributions the strategies make cognitive decoding process or students' developmental features (Tunçer \& Güven, 2007). One of the most extensive taxonomies was put forward by Weinstein and Mayer (1983, p. 3). These strategies are:

- Rehearsal strategies,

- Elaboration strategies, 
Cumhuriyet International Journal of Education-CIJE

e-ISSN: $2147-1606$

Vol 5 (3), 2016, $48-66$

- Organizational strategies,

- Comprehension monitoring strategies,

- Affective strategies.

The first one, the rehearsal strategies, are mostly utilized for basic learning tasks. These strategies are useful if learning encompasses some type of information. In this way, the students are able to select the crucial information and acquire it. Second group covers elaboration strategies which include constructing connections between the new information and already known. The third group, organizational strategies, means grouping different items under common features, listing and rearranging vocabulary. These strategies enable faster and easier comprehension. On the other hand, comprehension monitoring strategies include application of the techniques to achieve learning aims. The final type, affective strategies, implies the elimination of instinctive or sensitive obstacles arouse during the learning process (Güven, 2008).

Weinstein and Mayer (1986), asserted the students' self-awareness regarding the learning strategies for better learning is of great significance. For this reason, finding out the strategies utilized and integrating these into the courses are very important.

When the research studies carried out were examined, the results of investigations revealed that learning strategies help students learn on their own, ease the encoding process of information, support the retention of the learning (King \& McInerney, 2016; Kokkinos, Kargiotidis, \& Markos, 2015; Ruffing, Wach, Spinath, Brünken, \& Karbach, 2015; Ulstad, Halvari, Sørebø, \& Deci, 2016; Wahlheim, McDaniel, \& Little, 2016)

For example, in a study carried out by Baker and Boonkit (2004) about the importance of culture and context, learning strategies employed by undergraduate students at a Thai university studying English for Academic Purposes reading and writing courses were investigated. The results of the study indicated metacognitive, cognitive and compensation as the most frequently used strategies. Moreover, differences in strategy use for successful and less successful readers and writers were also revealed.

In another study, titled "The Place and Importance of Encoding Strategies in Social Sciences Courses" Tay (2004) gave information regarding learning, learning strategies and encoding strategies and tried to reveal the encoding strategies and emphasized the importance of these strategies. As a result of the study, the researcher recommended that social sciences course at the primary school level should include the use of learning strategies. This addition would decrease the use of rote memorization and facilitate better learning and retention.

So far, a great deal of research studies regarding the use of learning strategies have been carried out. For instance, Ames and Archer (1988) studied the perceptions of students related to goal orientation, use of effective learning strategies, task choices, attitudes, and causal attributions. The study was carried out with 176 students attending a junior high/high school for academically advanced students. The results revealed that students, perceiving an emphasis on mastery goals in the classroom indicated using more effective strategies, had a choice for challenging tasks, a more positive attitude toward the class, and a stronger belief that success follows from one's effort.

In another research carried out by Serin, Serin, and Şahin (2009), learning and studying strategies, and factors affecting locus of control of the students were analysed. The results of the study yielded that there was a meaningful differentiation among score means of motivation, anxiety, choosing main ideas and studying aids when learning and studying strategies of trainee teachers according to their gender were analysed. The researchers advised that male students need help in terms of learning and studying strategies. They also implied that learning and 
Cumhuriyet International Journal of Education-CIJE

e-ISSN: 2147-1606

Vol 5 (3), 2016, 48 - 66

studying strategies are to be integrated in and a part of the courses in order to teach these strategies effectively.

Samms and Friedel (2012) also performed a research study to find out relationship between dissimilar cognitive styles and use of learning strategies in undergraduate students. The students at six undergraduate classes participated in the study. The Motivated Strategies for Learning Questionnaire (MSLQ) was used to measure student learning strategies. The researchers found that for a majority of the classes, rehearsal was the primary study strategy which was used in these classes. It was also revealed that there was a relationship between cognitive-style gap and study strategies.

As implied in the research studies carried out, learning strategies, are crucial to raise the students' awareness, increase the productivity, provide the students with independent learning, help the students learn voluntarily and support the students development after their school life (Özer, 2001). However, using these strategies is not the only factor that affects learning. Academic self-efficacy, one of the most important concepts in learning, has also great influence in the learning process, since it has an impact on the learners' perception of learning. Academic selfefficacy is defined as "a self-perception of competence to effectively complete schoolwork and an expectation that one can succeed when faced with a challenging academic task" (Scheel \& Gonzalez, 2007, p. 50). As asserted by Zimmerman, Bandura, and Martinez-Pons (1992), selfefficacy beliefs of the students relate to such self-regulatory behaviours as completing homework, organizing school-related works and note-taking which are also a part of their academic selfefficacy beliefs and course goals. Various research studies have so far been carried out regarding relation between self-efficacy and achievement (Feldman \& Kubota, 2015; Griffin \& Gable, 2016; Høigaard, Kovač, Øverby, \& Haugen, 2015; Honicke \& Broadbent, 2016; Wilson \& Kim, 2016).

According to Bandura (1982), self-efficacy judgments, which affects the students' achievement and motivation to a great extent, are based on "previous performance attainments, vicarious experiences of observing the performances of others, verbal persuasion and allied types of social influences that one possesses certain capabilities; and physiological states from which people partly judge their capability, strength, and vulnerability (p. 126)". Along with these basic important components, he also added that self-efficacy beliefs can be developed from four main forms of influence which are mastery experiences, vicarious experiences, social persuasion and psychological and emotional states (Bandura, 1995). When the above mentioned qualities are taken into account, it is obvious that a student with higher academic self-efficacy are more relaxed and confident while carrying out schoolwork; on the contrary, students with lower self-efficacy are more stressful and anxious, and also their point of view is more limited while dealing with a problem or an activity (Eccles \& Wigfield, 1995). Therefore, it can be stated that self-confidence with regard to finishing a task or a finding a solution to a problem is helpful in terms of being calm and having a more thoughtful state. To this end, Lee (2003) implied that perceptions of selfefficacy have an effect on the behaviour in three different ways:

1. Self-efficacy influences choice of behaviour.

2. Self-efficacy influences the effort level expended on an activity or task.

3. Self-efficacy influence individuals' thought patterns and emotional reactions (p. 30).

Academic self-efficacy has been a topic of interest for many researchers. For example, in a study carried out by Chemers et al. (2001) about academic self-efficacy and first year college student performance and adjustment such variables as the effects of academic self-efficacy and optimism on students' academic performance, stress, health, and commitment to remain in school were examined. $1^{\text {st }}$ class students from University of California, Santa Cruz participated in the study. Two questionnaires about student self-reports regarding their perceived academic self- 
efficacy, social self-efficacy, general optimism, expected social adjustment and social support and ratings of stress and illness were administered. The results of the study showed that "academic self-efficacy and optimism were strongly related to performance and adjustment, both directly on academic performance and indirectly through expectations and coping perceptions (challengethreat evaluations) on classroom performance, stress, health, and overall satisfaction and commitment to remain in school (p. 61)".

Fettahloglu and Ekici (2011) also studied effect of teacher candidates' academic selfefficacy beliefs on their motivations towards sciences. The results indicated that the level of science teacher candidates' academic self-efficacy beliefs was average and academic self-efficacy explained $23 \%$ of the total variance pertaining to science motivation. Therefore, the researchers concluded that there was a positive significant relationship between self-efficacy and motivation.

In another research, effects of student motivation on performance in Web-based instruction (WBI) and applicability of the self-efficacy theory to these contexts were examined (Joo, Bong, \& Choi, 2000). The study was carried out in Korea and 152 high school students participated in the study. The path analysis carried out revealed that students' self-efficacy for self-regulated learning positively related to their academic self-efficacy, strategy use, and Internet self-efficacy. As a result of the study, it was implied that academic self-efficacy predicted students' performance on the written test.

Despite the ample research on learning strategies, awareness of these strategies and academic self-efficacy, little attention has been given to the effect of two constructs together and the relations between them. The studies indicated that students with high self-efficacy are inclined to utilize more strategies resulting in better performance and a correlation between self-efficacy and self-regulation, especially use of effective learning strategies (Chen, Chiu, \& Wang, 2015; Horn, Bruning, Schraw, Curry, \& Katkanant, 1993; Pajares \& Schunk, 2001).

In this study, it was aimed to examine teacher candidates' learning strategies and their level of academic self-efficacy. Furthermore, exploring the relations between learning strategies and academic self-efficacy and the effects of departments and gender on these variables were other goals of this study. As a result, it can be asserted that this study can be effective in terms of its contributions to create awareness regarding the learning strategies and academic self-efficacy for the teacher candidates at the very beginning of their education.

\section{METHOD}

\section{Research Design}

When researchers are interested in collecting information from a large group of people in order to describe some aspects or the characteristics of population, surveys are one of the most important tools (Fraenkel \& Wallen, 2006). Because of this, surveys are used as one of the most popular methods in the social sciences and the ongoing popularity of survey research is related to its being versatile, efficient, and generalizable (Groves et al., 2009). As a research method, survey research is defined as "any procedure to gather and describe the characteristics, attitudes, views, opinions, and so forth of students, teachers, administrators or any other people who are important to a study" (Brown \& Rodgers, 2002, p. 142). To this end, in the present research study, two separate surveys were used to collect data.

\section{Participants}

The target population of this study included all $1^{\text {st }}$ grade students enrolled at a faculty of education of a state university located in the Black Sea region in Turkey, in 2014-2015 Academic 
Cumhuriyet International Journal of Education-CIJE

e-ISSN: 2147-1606

Vol 5 (3), 2016, $48-66$

Year. The sample of the study composed of 256 students who were accessible during the data collection procedure $(\mathrm{N}=256)$. The frequencies and percentages regarding the students' gender and departments are presented in Table 1 and Table 2.

Table 1. Demographic Information Regarding Gender

\begin{tabular}{cccc}
\hline Gender & $f$ & \multicolumn{1}{c}{$\%$} \\
\hline Male & 67 & 26.2 & 73.8 \\
\hline
\end{tabular}

As can be seen in Table 1, of the sample, 189 students were females and 67 were males. In Table 2, department / division distributions of the students that comprise the sample are given.

Table 2. Demographic Information Regarding Departments of the Participants

\begin{tabular}{|c|c|c|c|}
\hline Department & Gender & $f$ & $\%$ \\
\hline \multirow{2}{*}{ Primary Education } & Male & 23 & \multirow{2}{*}{37.5} \\
\hline & Female & 73 & \\
\hline \multirow{2}{*}{ Social Studies Education } & Male & 23 & \multirow{2}{*}{23.0} \\
\hline & Female & 36 & \\
\hline \multirow{2}{*}{ Computer Education and Instructional Technologies } & Male & 18 & \multirow{2}{*}{11.3} \\
\hline & Female & 11 & \\
\hline \multirow{2}{*}{ Turkish Language Teaching } & Male & 1 & \multirow{2}{*}{4.7} \\
\hline & Female & 11 & \\
\hline \multirow{2}{*}{ Pre-School Teaching } & Male & 2 & \multirow{2}{*}{23.4} \\
\hline & Female & 58 & \\
\hline
\end{tabular}

In the above table, it can be observed that 96 students participated in the study from the Department of Primary Education, 59 were from the Department of Social Studies Education, 29 were from the Department of Computer Education and Instructional Technologies, 12 of them were from the Department of Turkish Language Teaching and 60 students were from the department of Pre-School Teaching.

\section{Data Collection Instruments}

For the data collection procedure, two surveys, one for learning strategies and another for academic self-efficacy, were used.

The first survey was "Motivated Strategies for Learning Questionnaire" (MSLQ). The original scale was developed by Pintrich and De Groot (1990). The adaptation of the scale was performed by Büyüköztürk, Akgün, Özkahveci, and Demirel (2004). MSLQ includes items related to motivation and learning strategies. The scale is composed of 6 motivation subscales and 9 learning strategies subscales. These subscales are modular meaning that the researcher can use one dimension or both of them depending on his or her purpose (Büyüköztürk et al., 2004).

The subscales for learning strategies are rehearsal, elaboration, organization, critical thinking metacognitive self-regulation, time/study environmental management, effort regulation, peer learning, help seeking. In the scale, the students rate themselves on a 7-point Likert scale, starting from 1 (not at all true of me) to 7 (very true of me). MSLQ was used in this study because it is appropriate for the university students and it a valid and reliable scale. When the scale first translated and analysed, Büyüköztürk et al. (2004) asserted that learning strategies can be used with 9 factors as in the original scale. However, Vural (2012) reanalysed the scale in terms of validity, reliability and factorial structure. After carrying out the analysis, he concluded 
Cumhuriyet International Journal of Education-CIJE

e-ISSN: 2147-1606

Vol 5 (3), 2016, $48-66$

that the Turkish version of the scale has a four-factor structure with 24 items. The total Cronbach's Alpha Coefficient for internal consistency reliability of the scale was found as $a=.88$.

Table 3. Cronbach's Alpha Coefficients for Learning Strategies Scale According to Factor Structures

\begin{tabular}{lc}
\hline Name of the Factor & Alpha (a) \\
\hline Association strategies & .82 \\
Rehearsal, organization, metacognitive self-regulation strategies & .80 \\
Time/study environmental strategies & .75 \\
Peer learning and help seeking strategies & .65 \\
\hline
\end{tabular}

The second survey, Academic Self-Efficacy Scale, was developed by Jerusalem and Schwarzer (1981: as cited in Yılmaz, Gürçay and Ekici). The scale has 7 items based on 4-point Likert scale, starting from 1 (Totally disagree) to 4 (Totally agree). The total points that one can get from the scale range from 7 to 28 and higher scores indicate high level of academic self-efficacy.

The original study of the scale was carried out with 68 medical school students and Cronbach's Alpha Coefficient for internal consistency reliability was calculated as $a=.87$. The adaptation studies of the scale, which was originally written in German, was performed by Yilmaz et al. (2007). Initially, exploratory factor analysis was carried out and the results revealed that $45 \%$ of the total variance was explained by a single factor. In addition, Cronbach's Alpha Coefficient for internal consistency reliability was calculated as $a=.79$. Finally, it was stated that the scale can be used as a reliable and valid instrument to determine the academic self-efficacy levels of university students in Turkey.

\section{Data Analysis}

Descriptive statistics was employed to explore the characteristics of the sample in terms of gender, department/division, learning strategies and level of academic self-efficacy. Furthermore, to find out if there was a relationship between the teacher candidates' learning strategies and their level of academic self-efficacy, bivariate correlation analysis was employed. In addition, MANOVA was carried out to investigate the differences regarding learning strategies and academic self-efficacy with regard to gender and departments. The analyses were carried out with SPSS 21 (Statistical Package for Social Sciences) for Windows.

\section{RESULTS}

In this study, the initial aim was to find out the learning strategies the teacher candidates utilize and their level of academic self-efficacy. In addition, the possible relations between these variables and teacher candidates' gender and departments were also tried to be revealed through the analyses carried out. To this end, four research questions were asked to explore the learning strategies and academic self-efficacy.

The first research question was whether there was a relationship between teacher candidates' level of academic self-efficacy and the learning strategies they utilized. In order to find out the existence of such relationship correlation coefficients were computed regarding the two variables (Table 4 ).

As presented in the table, academic self-efficacy significantly correlated with the learning strategies: rehearsal, organization, metacognitive self-regulation strategies, $\mathrm{r}=.26, \mathrm{n}=256 \mathrm{p}<.01$; association strategies, $\mathrm{r}=.35, \mathrm{n}=256 \mathrm{p}<.01$; time/study environmental strategies, $\mathrm{r}=.33, \mathrm{n}=256$ $\mathrm{p}<.01$ and peer learning and help seeking strategies, $r=.13, \mathrm{n}=256 \mathrm{p}<.05$. Therefore, it can be stated 
Cumhuriyet International Journal of Education-CIJE

e-ISSN: $2147-1606$

Vol 5 (3), 2016, $48-66$

that $52 \%$ of the variance of the level of self-efficacy is accounted for by its linear relationship with the rehearsal, organization, metacognitive self-regulation strategies, $70 \%$ of variance with association strategies, $66 \%$ of variance with time/study environmental strategies and $26 \%$ of the variance with peer learning and help seeking strategies.

Table 4. Correlations between Academic Self-Efficacy and Learning Strategies

\begin{tabular}{cccccc}
\hline & & Rehearsal & Association & Time/study & Peer learning \\
\hline & Pearson Correlation & .264 & .350 & .329 & .130 \\
Academic & Sig. (2-tailed) & .000 & .000 & .000 & .038 \\
Self-Efficacy & $\mathrm{N}$ & 256 & 256 & 256 & 256 \\
\hline
\end{tabular}

The second research question was "What are the learning strategies the teacher candidates' use with regard to their departments and gender?". To find out the different strategies, descriptive statistics was employed and the means and standard deviations were calculated.

Table 5. Descriptive Statistics Results Regarding Learning Strategies

\begin{tabular}{llcc}
\hline & $M$ & $S D$ & $N$ \\
\hline Learning Strategies & & & \\
Rehearsal, organization, metacognitive self-regulation strategies & 5.68 & .97 & 256 \\
Association strategies & 5.05 & 1.21 & 256 \\
Time/study environmental strategies & 5.28 & 1.19 & 256 \\
Peer learning and help seeking strategies & 5.29 & 1.27 & 256 \\
\hline
\end{tabular}

As indicated in Table 5, use of learning strategies at this level is above the scale average. It is also clear that $1^{\text {st }}$ grade teacher candidates mostly utilize "rehearsal, organization, metacognitive self-regulation strategies" while studying $(M=5.68, S D=.97)$. Besides these strategies, using "time/study environmental strategies" $(M=5.28, S D=1.19)$ and "peer learning and help seeking strategies" $(M=5.29, S D=1.27)$ are also common among the participants.

Table 6. Descriptive Statistics Results Regarding Learning Strategies with regard to Departments

\begin{tabular}{|c|c|c|c|c|}
\hline Learning Strategies & Departments & $M$ & $S D$ & $N$ \\
\hline \multirow{5}{*}{$\begin{array}{l}\text { Rehearsal, organization, metacognitive self-regulation } \\
\text { strategies }\end{array}$} & Primary Education & 5.44 & .12 & 96 \\
\hline & Social Studies Education & 6.04 & .68 & 59 \\
\hline & CEIT & 5.30 & .95 & 29 \\
\hline & Turkish Language Teaching & 6.04 & .65 & 12 \\
\hline & Pre-School Teaching & 5.81 & .84 & 60 \\
\hline \multirow{5}{*}{ Association strategies } & Primary Education & 4.91 & 1.16 & 96 \\
\hline & Social Studies Education & 5.40 & .93 & 59 \\
\hline & CEIT & 4.96 & .89 & 29 \\
\hline & Turkish Language Teaching & 5.67 & 2.97 & 12 \\
\hline & Pre-School Teaching & 4.86 & 1.00 & 60 \\
\hline \multirow{5}{*}{ Time/study environmental strategies } & Primary Education & 5.09 & 1.24 & 96 \\
\hline & Social Studies Education & 5.52 & 1.18 & 59 \\
\hline & CEIT & 5.13 & 1.06 & 29 \\
\hline & Turkish Language Teaching & 5.31 & 1.37 & 12 \\
\hline & Pre-School Teaching & 5.40 & 1.12 & 60 \\
\hline \multirow{5}{*}{ Peer learning and help seeking strategies } & Primary Education & 5.15 & 1.44 & 96 \\
\hline & Social Studies Education & 5.42 & 1.34 & 59 \\
\hline & CEIT & 5.44 & .96 & 29 \\
\hline & Turkish Language Teaching & 5.42 & 1.19 & 12 \\
\hline & Pre-School Teaching & 5.29 & 1.05 & 60 \\
\hline
\end{tabular}


When the distribution of strategies according to the departments were explored, it was observed that the highest mean scores were for the Rehearsal, organization, metacognitive selfregulation strategies. Teacher candidates studying at the departments of Social Studies Education $(M=6.04, S D=.68)$ and Turkish Language Teaching $(M=6.04, S D=.65)$ mostly utilized these strategies. On the contrary, using association strategies had the lowest mean scores especially for the departments of Pre-School Teaching $(M=4.86, S D=1.00)$ and Primary Education $(M=4.91$, $S D=1.16$ ), (Table 6).

As for the third research question, academic self-efficacy levels were analysed in terms of departments and gender. The results indicated that the teacher candidates had an overall high academic self-efficacy levels because the mean scores of all participants were closer to the highest score that can be taken from the scale $(M=20.82, S D=3.40)$, (Table 7$)$.

Table 7. Overall Academic Self-Efficacy Level of the Participants

\begin{tabular}{cccc}
\hline & $M$ & $S D$ & $N$ \\
\hline Academic Self-Efficacy & 20.82 & 3.40 & 256 \\
\hline
\end{tabular}

Upon analyzing the academic self-efficacy levels in terms of participants' gender, it was revealed that the level of male teacher candidates' academic self-efficacy level $(M=21.16, S D=$ .38 ) was higher than the female teacher candidates' $(M=20.70, S D=.25)$, (Table 8).

Table 8. Academic Self-Efficacy Levels with regard to Gender

\begin{tabular}{|c|c|c|c|c|}
\hline Self-Efficacy & Gender & $M$ & $S D$ & $N$ \\
\hline \multirow{2}{*}{ Academic Self-Efficacy } & Male & 21.16 & .38 & 67 \\
\hline & Female & 20.70 & .25 & 189 \\
\hline
\end{tabular}

Table 9. Academic Self-Efficacy Levels in terms of Departments and Gender

\begin{tabular}{|c|c|c|c|c|c|}
\hline Self-Efficacy & Departments & Gender & $M$ & $S D$ & $N$ \\
\hline \multirow{15}{*}{ Academic Self-Efficacy } & \multirow{3}{*}{ Primary Education } & Male & 20.12 & 3.81 & 23 \\
\hline & & Female & 20.90 & 3.15 & 73 \\
\hline & & Total & 20.72 & 3.31 & 96 \\
\hline & \multirow{3}{*}{ Social Studies Education } & Male & 21.91 & 2.59 & 23 \\
\hline & & Female & 21.76 & 2.98 & 36 \\
\hline & & Total & 21.82 & 2.81 & 59 \\
\hline & \multirow{3}{*}{ CEIT } & Male & 21.40 & 2.71 & 18 \\
\hline & & Female & 21.03 & 3.46 & 11 \\
\hline & & Total & 21.26 & 2.96 & 29 \\
\hline & \multirow{3}{*}{ Turkish Language Teaching } & Male & 22.00 & $\cdot$ & 1 \\
\hline & & Female & 20.74 & 5.11 & 11 \\
\hline & & Total & 20.85 & 4.89 & 12 \\
\hline & \multirow{3}{*}{ Pre-School Teaching } & Male & 22.00 & 2.83 & 2 \\
\hline & & Female & 19.72 & 3.73 & 58 \\
\hline & & Total & 19.79 & 3.71 & 60 \\
\hline
\end{tabular}

In order to explore the differences in academic self-efficacy levels further analysis were carried out based on the candidates' departments and gender. The results indicated that male candidates studying at the department of Social Studies Education $(M=21.91, S D=2.59)$ and CEIT $(M=21.40, S D=2.71)$ had higher academic self-efficacy. However, female candidates especially the ones studying at the department of Pre-School Teaching $(M=19.72, S D=3.73)$ had lower academic self-efficacy (Table 9). 
To find out whether the differences found in the descriptive analysis in terms of gender and departments regarding the learning strategies and academic self-efficacy levels were significant, a multivariate analysis of variance was carried out. As presented in Table 10, there was a significant multivariate effect with regards to departments, Wilks' $\lambda=.88, F(4,803.573)=$ $1.64, \mathrm{p} \leq .04$, partial eta squared $=.33$. According to analysis, observed power was .91 for departments.

Table 10. MANOVA Results for Gender and Departments

\begin{tabular}{ccccccccc}
\hline Effect & Wilks' Lambda & $\mathrm{F}$ & $\mathrm{df}$ & Error df & $p$ & $\eta^{2}$ & Observed Power \\
\hline Intercept & .07 & 646.52 & 5.000 & 242.000 & .00 & .93 & 1.000 \\
Departments & .88 & 1.638 & 20.000 & 803.573 & .04 & .033 & .906 \\
Gender & .96 & 2.109 & 5.000 & 242.000 & .06 & .042 & .693 \\
Department \& Gender & .93 & .876 & 20.000 & 803.573 & .62 & .018 & .581 \\
\hline
\end{tabular}

In Table 11, the multivariate main effects were examined in order to understand on which dependent variable "departments" and "gender" had a significant effect. Significant multivariate main effects for departments were obtained in terms of rehearsal, organization, metacognitive self-regulation strategies, $F(4,256)=6.39, p<.01$, partial eta square $=.94$, power $=.99$. The results showed that there was a significant effect of "departments" on one factor of learning strategies. Post hoc analyses were conducted given the statistically significant MANOVA test. Specifically, Tukey HSD tests were conducted on all possible pairwise contrasts. The following pairs of departments were found to be significantly different $(\mathrm{p}<.05)$ for rehearsal, organization, metacognitive self-regulation strategies: primary school education $(M=5.44, S D=.12)$ and social sciences education $(M=6.04, \mathrm{SD}=.68)$, and social sciences education and CEIT $(M=5.30, \mathrm{SD}=$ .95). In other words, teacher candidates enrolled at the department of social sciences education use statistically significantly more rehearsal, organization, metacognitive self-regulation strategies than the candidates enrolled in either of the two other departments. Furthermore, "gender" had also a significant effect on the same type of strategy, $F(4,256)=5.10, p<.05$, partial eta square $=.02$, power $=.61$. Therefore, it can be stated that the use of rehearsal, organization, metacognitive self-regulation strategies by female students $(M=5.78, S D=.90)$ is significantly higher than those of male students $(M=5.38, S D=.97)$.

Table 11. Tests of Between-Subjects Effects for Gender and Departments 


\begin{tabular}{|c|c|c|c|c|c|c|}
\hline Source & Dependent Variable & $\mathrm{df}$ & Mean Square & $F$ & $p$ & $\eta^{2}$ \\
\hline \multirow[t]{5}{*}{ Intercept } & Self-Efficacy & 1 & 23773.750 & 2090.946 & .000 & .895 \\
\hline & Rehearsal & 1 & 1624.210 & 1919.351 & .000 & .886 \\
\hline & Association & 1 & 1397.891 & 963.512 & .000 & .797 \\
\hline & Time / Study & 1 & 1489.586 & 1074.337 & .000 & .814 \\
\hline & Peer Learning & 1 & 1407.494 & 867.239 & .000 & .779 \\
\hline \multirow[t]{5}{*}{ Departments } & Self-Efficacy & 4 & 13.856 & 1.219 & .303 & .019 \\
\hline & Rehearsal & 4 & 5.408 & 6.390 & .000 & .094 \\
\hline & Association & 4 & 2.850 & 1.965 & .100 & .031 \\
\hline & Time / Study & 4 & 3.139 & 2.264 & .063 & .036 \\
\hline & Peer Learning & 4 & 1.278 & .788 & .534 & .013 \\
\hline \multirow[t]{5}{*}{ Gender } & Self-Efficacy & 1 & 5.673 & .499 & .481 & .002 \\
\hline & Rehearsal & 1 & 4.312 & 5.096 & .025 & .020 \\
\hline & Association & 1 & .016 & .011 & .915 & .000 \\
\hline & Time / Study & 1 & .210 & .152 & .697 & .001 \\
\hline & Peer Learning & 1 & 4.769 & 2.938 & .088 & .012 \\
\hline Department* & Self-Efficacy & 4 & 5.800 & .510 & .728 & .008 \\
\hline \multirow[t]{4}{*}{ Gender } & Rehearsal & 4 & 1.371 & 1.620 & .170 & .026 \\
\hline & Association & 4 & .125 & .086 & .987 & .001 \\
\hline & Time / Study & 4 & 1.587 & 1.145 & .336 & .018 \\
\hline & Peer Learning & 4 & .418 & .258 & .905 & .004 \\
\hline
\end{tabular}

\section{DISCUSSION}

The purpose of the present study was to explore teacher candidates' learning strategies and academic self-efficacy levels. Moreover, the relations between the two variables and other factors, such as departments and gender, were examined in this study.

Initially, descriptive analysis was performed to find out learning strategies and academic self-efficacy levels. As a result of the analysis rehearsal, organization, metacognitive selfregulation strategies came to fore as the most applied strategies among the participants. The results were supported by studies that also suggested that the teacher candidates basically use rehearsal strategies while studying (Çelikkaya, 2010; Haşlaman \& Aşkar, 2007; Kete \& Sucuoğlu, 2011; Selçuk, Karabey, \& Çalışkan, 2011). Further analysis was carried out in order to determine the differences in terms of departments. The findings revealed that the teacher candidates enrolled at Social Studies Education and Turkish Language Teaching utilized these strategies more than other departments. To this end, Lyons-Wagner (2010) implied that rehearsal strategies were used most frequently among all achievement levels. Kete and Sucuoğlu (2011), although had similar results related to the use of strategies, found out that teacher candidates at the biology and science teaching departments prefer these strategies more than other ways to learn. However, some other studies had different results regarding the use of strategies. For instance, Balkıs, Duru, Buluş, and Duru (2011) stated that teacher candidates mostly use deep learning strategies and Çelenk and Karakış (2007) found out that they mostly use cognitive regulation strategies. Furthermore, Arsal (2005) indicated that teacher candidates utilize association strategies and Şahin and Çakar (2011) asserted that teacher candidates use rehearsal strategies less than other strategies.

With regard to rehearsal, elaboration, and organizational strategies, Pintrich (1999) stated that although these strategies are important in terms of academic performance, they mostly 
include simple memory tasks (or rote memorization), and comprehension of a written text to some extent. In addition, C. E. Weinstein and Mayer (1986) indicated that the use of rehearsal strategies start from childhood. The findings of this study related to rehearsal, elaboration, and organizational strategies might suggest a number of relations between different variables. The multiple choice exam types and especially the university entrance exam can be an important factor directing the teacher candidates to the use of rehearsal strategies. Because the question types in these exams, mostly multiple choice questions, require the students to repeat and recall information, words or lists. Moreover, the studying habits which are based on preparing for the exams just before the exam date, the methods used in the courses and type of questions may stimulate the teacher candidates to this direction. Research studies carried out at the lower academic levels, primary schools or high schools, also indicated similar results (Dikbaş \& Hasırc1, 2008; Kontaş, 2010; Tay \& Yangın, 2008). On the contrary, association strategies were the least used among other strategies by the teacher candidates. As a result of detailed analysis based on departments, it was observed that Primary Education, CEIT and Pre-School Teaching had lower means indicating the insufficient use of these type strategies.

Determining the academic self-efficacy levels of teacher candidates was another important aspect of the research. The results of descriptive analysis indicated that the teacher candidates had high level of academic self-efficacy and when the gender variable was taken into account, although not a significant difference was found, it was observed that male candidates had higher self-efficacy than female participants. With regard to having high academic self-efficacy at the university level, some other research studies also had similar findings (Akbay \& Gizir, 2010; Özsüer, Inal, Uyanik, \& Ergün, 2011; Yılmaz et al., 2007). When gender variable is considered, it was found out that there were different findings. Some researchers had similar results and stated that male students have higher self-efficacy (Azar, 2012; Busch, 1995; Hackett, 1985; Satıc1, 2013; Shkullaku, 2013; Üredi \& Üredi, 2005), while other researchers asserted opposite findings (Akbaş \& Çelikkaleli, 2006; Kahyaoğlu \& Yangın, 2007; Özdemir, 2008). Thus, it can be concluded that gender can be a factor creating the difference in self-efficacy levels; however, the difference can be in either way. Therefore, it is still early to talk about gender as an effective factor on academic self-efficacy.

The students with higher academic self-efficacy study harder and when they face difficulties they do not give in; furthermore, they use learning strategies productively and they are academically successful individuals (Zimmerman et al., 1992). Based on this idea, it can be concluded that the teacher candidates' having high self-efficacy indicates with some methodological help these students can achieve better things and they can use more cognitive strategies.

As a next step in the analysis, the correlation between the four factors of learning strategies and academic self-efficacy were looked into. The results showed that there were significant correlations between the variables. The significance between rehearsal, organization, metacognitive self-regulation strategies, association strategies, time/study environmental strategies and academic self-efficacy was $p<.01$ and as for the peer learning and help seeking strategies, the significance was $\mathrm{p}<.05$. This meant that higher academic self-efficacy results in more and better use of learning strategies, which also corresponds to the theory behind selfefficacy. Because the students with higher self-efficacy show greater persistence and endurance while learning, they might utilize different learning strategies to attain their goals. In their study, Youngju, Jae-Eun, BoKyung, YooKyung, and Se-Bin (2007) also stated similar findings and indicated that "academic self-efficacy had the greatest effect on learning strategy (p. 6)". Based on their findings they suggested that educational policies should be based on increasing students' 
Cumhuriyet International Journal of Education-CIJE

e-ISSN: $2147-1606$

Vol 5 (3), 2016, 48 - 66

academic self-efficacy. Some other researchers also came up with parallel result and stressed the correlation between the two variables (Ames \& Archer, 1988; Elliot, McGregor, \& Gable, 1999; Multon, Brown, \& Lent, 1991). On the contrary, Mohsenpour, Hejazi, and Kiamanesh (2008) expressed that self-efficacy was a negative predictor of learning strategies.

For the final research question, MANOVA analysis was performed and the results showed that there was a significant difference between departments and rehearsal strategies and between gender and rehearsal strategies. As the findings of the descriptive studies also suggested the teacher candidates' inclination towards the use of a specific learning strategy is also shaped by the departments and gender. These might mean that the teacher candidates enrolled at Social Sciences Education and Turkish Language Education are prone to memorization and repetition of the teaching materials. The instructors teaching at these departments should give more importance to more meaningful methods and should teach the teacher candidates how to learn. Moreover, the significant finding regarding gender means that male students consult these strategies more than female participants. Therefore, importance must be given to the teaching of the use of different and effective learning strategies to both sexes, especially male teacher candidates.

In this study, mainly the relationship between the learning strategies and academic selfefficacy were tried to be explored. As a second point to consider, the effect of departments and gender on the two variables and a significant effect between learning strategies and academic selfefficacy and between departments, gender and rehearsal strategies were found out. When the overall research is taken into account it can be suggested that increasing the teacher candidates' awareness regarding the learning strategies and academic self-efficacy is of great importance. To this end, some courses or at least activities related to learning strategies are to be added to the curricula. Because the two variables are not limited to the school life, they affect the individuals' life after graduation to a great extent. Furthermore, the instructors at the university level should be role models for the teacher candidates in terms of learning strategies.

\section{Limitations of The Study}

A limitation of the study was the use of convenient sampling. In addition, using a single domain in a single context may limit the application of the findings to the other settings. Therefore, the first limitation was related to the selection of the participants because only the teacher candidates enrolled at a university in Western Black Sea Region participated in the study, which might create a threat to generalizability and as a result external validity. In addition, mixed methods design should be used to verify the collected data through qualitative methods such as classroom observations and in-depth interviews. This can be a constraint in terms of objectivity of the study. Finally, other variables such other the decisions of individuals who may also affect the process on learning and some outcome variables such as academic achievement were ignored in the study. 


\section{REFERENCES}

Açıkgöz, K. Ü. (2005). Etkili öğrenme ve öğretme. İzmir: Eğitim Dünyası Yayınları.

Akbaş, A., \& Çelikkaleli, Ö. (2006). Sınıf öğretmeni adaylarının fen öğretimi özyeterlik inançlarının cinsiyet, öğrenim türü ve üniversitelerine göre incelenmesi. Mersin Üniversitesi Eğitim Fakültesi Dergisi, 2(1), 98-110.

Akbay, S. E., \& Gizir, C., A. (2010). Cinsiyete göre üniversite öğrencilerinde akademik erteleme davranışı: Akademik güdülenme, akademik özyeterlik ve akademik yükleme stillerinin rolü. Mersin Üniversitesi Ĕ̆itim Fakültesi Dergisi, 6(1), 60-78.

Ames, C., \& Archer, J. (1988). Achievement goals in the classroom: Students' learning strategies and motivation processes. Journal of Educational Psychology, 80(3), 260.

Arsal, Z. (2005). Öğretmen adaylarının öğrenme ve motivasyon stratejileri. Paper presented at the XIV. Ulusal Eğitim Bilimleri Kongresi Bildirileri.

Azar, A. (2012). Ortaöğretim fen bilimleri ve matematik öğretmeni adaylarının öz yeterlilik inançları. Uluslararası Yönetim İktisat ve İşletme Dergisi, 6(12), 235-252.

Baker, W., \& Boonkit, K. (2004). Learning strategies in reading and writing: EAP contexts. RELC Journal, 35(3), 299-328.

Bal, A. P. (2013). Investigating Undergraduate Students' Assessment Preferences in Mathematics Course and Learning Strategies. International Online Journal of Educational Sciences, 5(1), 242-257.

Balkıs, M., Duru, E., Buluş, M., \& Duru, S. (2011). Tükenmişliğin öğretmen adayları arasındaki yaygınlığı, demografik değişkenler ve akademik başarı ile ilişkisi. Pamukkale Üniversitesi Eğitim Fakültesi Dergisi, 29(1), 151-165.

Bandura, A. (1982). Self-efficacy mechanism in human agency. American psychologist, 37(2), 122.

Bandura, A. (1995). Self-efficacy in changing societies. New York: Cambridge University Press.

Brown, J. D., \& Rodgers, T. S. (2002). Doing second language research: An introduction to the theory and practice of second language research for graduate/master's students in TESOL and applied linguistics, and others: Oxford University Press.

Busch, T. (1995). Gender differences in self-efficacy and attitudes toward computers. Journal of educational computing research, 12(2), 147-158.

Büyüköztürk, Ş., Akgün, Ö. E., Özkahveci, Ö., \& Demirel, F. (2004). Güdülenme ve öğrenme stratejileri ölçeğinin Türkçe formunun geçerlik ve güvenirlik çalışması. Kuram ve Uygulamada Eğitim Bilimleri, 4(2), 207-239.

Carns, A. W., \& Carns, M. R. (1991). Teaching study skills, cognitive strategies, and metacognitive skills through self-diagnosed learning styles. School Counselor, 38, 341-346.

Chamot, A. U. (2004). Issues in language learning strategy research and teaching. Electronic journal of foreign language teaching, 1(1), 14-26.

Chemers, M. M., Hu, L.-t., \& Garcia, B. F. (2001). Academic self-efficacy and first year college student performance and adjustment. Journal of Educational Psychology, 93(1), 55.

Chen, B. H., Chiu, W.-C., \& Wang, C.-C. (2015). The Relationship Among Academic Self-concept, Learning Strategies, and Academic Achievement: A Case Study of National Vocational College Students in Taiwan via SEM. The Asia-Pacific Education Researcher, 24(2), 419-431.

Commander, N. E., \& Smith, B. D. (1995). Developing adjunct reading and learning courses that work. Journal of Reading, 38(5), 352-360. 
Cumhuriyet International Journal of Education-CIJE

e-ISSN: $2147-1606$

Vol 5 (3), 2016, 48 - 66

Çelenk, S., \& Karakış, Ö. (2007). Farklı Öğrenme Stillerine Sahip Öğrencilerin Genel Öğrenme Stratejilerini Kullanma Düzeyleri. АİBய̈ Örneği"”", АİBÜ Eğitim Fakültesi Dergisi, 7(2), 3452.

Çelikkaya, T. (2010). Sosyal bilgiler öğretmen adaylarının kullandıkları öğrenme stratejileri. Ahi Evran Üniversitesi Ĕ̆itim Fakültesi Dergisi, 11(3), 65-84.

Dikbaş, Y., \& Hasırcı, K. Ö. (2008). Öğrenme stratejileri öğretiminin ve ders işlenişinde kullanımının öğrencilerin akademik başarılarına ve tutumlarına etkisi. Ahi Evran Üniversitesi Kırşehir Eğitim Fakültesi Dergisi, 2, 70.

Eccles, J. S., \& Wigfield, A. (1995). In the mind of the actor: The structure of adolescents' achievement task values and expectancy-related beliefs. Personality and Social Psychology Bulletin, 21(3), 215-225.

Elliot, A. J., McGregor, H. A., \& Gable, S. (1999). Achievement goals, study strategies, and exam performance: A mediational analysis. Journal of Educational Psychology, 91(3), 549.

Feldman, D. B., \& Kubota, M. (2015). Hope, self-efficacy, optimism, and academic achievement: Distinguishing constructs and levels of specificity in predicting college grade-point average. Learning and Individual Differences, 37, 210-216.

Fettahlioglu, P., \& Ekici, G. (2011). Affect of teacher candidates' academic self-efficacy beliefs on their motivations towards sciences. Procedia-Social and Behavioral Sciences, 15, 2808-2812.

Fraenkel, J., \& Wallen, N. E. (2006). How to design and evaluate research in education. New York, NY: McGraw-Hill Companies.

Griffin, C. S., \& Gable, R. K. (2016). Analyzing the Relationship of Voluntary Student Participation in Optional Exam Review Sessions with Academic Self-Efficacy and Academic Performance.

Grigerenko, E. L., \& Sternberg, R. J. (1995). Thinking styles In D. H. Saklofske \& M. Zeidner (Eds.), International handbook of personality and intelligence. New York: Springer.

Groves, R. M., Fowler, F. J., Couper, M. P., Lepkowski, J. M., Singer, E., \& Tourangeau, R. (2009). Survey methodology (Vol. 561): Wiley.

Güven, M. (2008). Development of learning strategies scale: study of validation and reliability. World Applied Sciences Journal, 4(1), 31-36.

Hackett, G. (1985). Role of mathematics self-efficacy in the choice of math-related majors of college women and men: A path analysis. Journal of counseling psychology, 32(1), 47.

Hamurcu, H. (2002). Okulöncesi öğretmen adaylarının kullandıkları öğrenme stratejileri. Hacettepe Üniversitesi Eğitim Fakültesi Dergisi, 23, 127-134.

Haşlaman, T., \& Aşkar, P. (2007). Programlama dersi ile ilgili özdüzenleyici öğrenme stratejileri ve başarı arasındaki ilişkinin incelenmesi. Hacettepe Üniversitesi Eğitim Fakültesi Dergisi, 32, 110-122.

Høigaard, R., Kovač, V. B., Øverby, N. C., \& Haugen, T. (2015). Academic self-efficacy mediates the effects of school psychological climate on academic achievement. School Psychology Quarterly, 30(1), 64.

Honicke, T., \& Broadbent, J. (2016). The influence of academic self-efficacy on academic performance: A systematic review. Educational Research Review, 17, 63-84.

Horn, C., Bruning, R., Schraw, G., Curry, E., \& Katkanant, C. (1993). Paths to success in the college classroom. Contemporary educational psychology, 18(4), 464-478.

Joo, Y.-J., Bong, M., \& Choi, H.-J. (2000). Self-efficacy for self-regulated learning, academic selfefficacy, and internet self-efficacy in Web-based instruction. Educational Technology Research and Development, 48(2), 5-17. 
Cumhuriyet International Journal of Education-CIJE

e-ISSN: $2147-1606$

Vol 5 (3), 2016, $48-66$

Kahyaoğlu, M., \& Yangın, S. (2007). İlköğretim öğretmen adaylarının mesleki özyeterliklerine ilişkin görüşleri. Kastamonu Education Journal, 15(1), 73-84.

Kete, R., \& Sucuoğlu, H. (2011). Biyoloji ve Fen Bilgisi Ö ğretmen Adaylarının Kullandığı Öğrenme Stratejileri (DEÜ. Örneği). Ilkogretim Online, 10(1).

King, R. B., \& McInerney, D. M. (2016). Examining the links between social goals and learning strategies The Psychology of Asian Learners (pp. 405-417): Springer.

Kokkinos, C. M., Kargiotidis, A., \& Markos, A. (2015). The relationship between learning and study strategies and big five personality traits among junior university student teachers. Learning and Individual Differences, 43, 39-47.

Kontaş, H. (2010). Üstün yetenekli ilköğretim öğrencilerinin öğrenme stratejileri. Ilkogretim Online, 9(2), 1148-1158.

Lee, E. E. (2003). Cultural mistrust, university alienation, academic self-efficacy and academic help seeking in African American college students. (Ph.D.), University of Nebraska, Lincoln, Nebraska.

Lyons-Wagner, E. C. (2010). The effects of a self-regulation learning-strategies instructional program on middle-school students' use of learning strategies and study tools, self-efficacy, and history test performance. (Ph.D.), University of San Francisco, San Francisco.

Mattarima, K., \& Hamdam, A. R. (2011). Understanding students' learning strategies as an input context todesign English classroom activities. International Journal of Psychological Studies, $3(2), \mathrm{p} 238$.

Mohsenpour, M., Hejazi, E., \& Kiamanesh, A. (2008). The roal of self-efficacy, achievement goals, learning strategies and persistence in math achievement of 11th grade high school students in Tehran. Journal of Educational Innovations, 24, 153-172.

Multon, K. D., Brown, S. D., \& Lent, R. W. (1991). Relation of self-efficacy beliefs to academic outcomes: A meta-analytic investigation. Journal of counseling psychology, 38(1), 30.

Özdemir, S. M. (2008). Sınıf öğretmeni adaylarının öğretim sürecine ilişkin öz-yeterlik inançlarının çeşitli değişkenler açısından incelenmesi. Kuram ve Uygulamada Eğitim Yönetimi, 54, 277-306.

Özer, B. (2001). Öğrenmeyi öğretme, öğretimde planlama ve değerlendirme. Eskişehir: Anadolu Üniversitesi Yaymları, 161-172.

Özsüer, S., Inal, G., Uyanik, Ö., \& Ergün, M. (2011). Afyon Kocatepe Üniversitesinde öğrenim gören öğrencilerin akademik öz-yeterlik inanç düzeylerinin incelenmesi. Afyon Kocatepe University Journal of Social Sciences, 13(2).

Pajares, F., \& Schunk, D. (2001). The development of academic self-efficacy. In A. Wigfield \& J. Eccles (Eds.), Development of achievement motivation. San Diego: Academic Press.

Pintrich, P. R. (1999). The role of motivation in promoting and sustaining self-regulated learning. International journal of educational research, 31(6), 459-470.

Pintrich, P. R., \& De Groot, E. V. (1990). Motivational and self-regulated learning components of classroom academic performance. Journal of Educational Psychology, 82(1), 33-40.

Prensky, M. (2010). Teaching digital natives: Partnering for real learning. Newbury Park, CA: Corwin.

Roehl, A., Reddy, S. L., \& Shannon, G. J. (2013). The Flipped Classroom: An Opportunity To Engage Millennial Students Through Active Learning Strategies. Journal of Family $\mathcal{E}$ Consumer Sciences, 105(2), 44-49.

Ruffing, S., Wach, F.-S., Spinath, F. M., Brünken, R., \& Karbach, J. (2015). Learning strategies and general cognitive ability as predictors of gender-specific academic achievement. Frontiers in psychology, 6. 
Cumhuriyet International Journal of Education-CIJE

e-ISSN: $2147-1606$

Vol 5 (3), 2016, $48-66$

Samms, C. L., \& Friedel, C. R. (2012). Relationship between dissimilar cognitive styles and use of learning strategies in undergraduate students. Academy of Educational Leadership Journal, 16(3), 113-130.

Satıcı, S. A. (2013). Üniversite öğrencilerinin akademik öz-yeterliklerinin çeşitli değiş̧kenler açısından incelenmesi. (Ms.D.), Anadolu Üniversitesi, Eskişehir.

Scheel, M. J., \& Gonzalez, J. (2007). An investigation of a model of academic motivation for school counseling. Professional School Counseling, 11(1), 49-56.

Schunk, D. H. (1991). Self-efficacy and academic motivation. Educational psychologist, 26(3-4), 207231.

Selçuk, G. S., Karabey, B., \& Çalışkan, S. (2011). How candidate teachers use learning strategies in physics: The effects of gender And department. Gaziantep Univeristy Journal of Social Sciences, 10(2), 787-801.

Serin, O., Serin, N. B., \& Şahin, F. S. (2009). Factors affecting the learning and studying strategies, and locus of control of the trainee teachers. Procedia-Social and Behavioral Sciences, 1(1), 11271136.

Shkullaku, R. (2013). The Relationship between Self - efficacy and Academic Performance in the Context of Gender among Albanian Students European Academic Research, 1(4), 467-478.

Şahin, H., \& Çakar, E. (2011). Eğitim fakültesi öğrencilerinin öğrenme stratejileri ve akademik güdülenme düzeylerinin akademik başarılarına etkisi. Türk Ĕ̆itim Bilimleri Dergisi, 9(3), 519-540.

Tay, B. (2004). Sosyal bilgiler dersinde anlandırma stratejilerinin yeri ve önemi. Gazi Üniversitesi Kırşehir Eğitim Fakültesi Dergisi, 5(2), 1-12.

Tay, B., \& Yangın, B. (2008). 4. sinıf öğrencilerinin sosyal bilgiler dersinde sinıf ortamında kullandıkları öğrenme stratejileri. Ahi Evran Üniversitesi Kırşehir Ĕ̆itim Fakültesi Dergisi (KEFAD), 9(3), 73-88.

Tunçer, B. K., \& Güven, B. (2007). Öğretimde öğrenme stratejilerinin kullanımının öğrencilerin akademik başarıları, hatırda tutma düzeyleri ve derse ilişkin tutumları üzerindeki etkisi. Yüzüncü Yıl Üniversitesi, Ĕ̈itim Fakültesi Dergisi, 4(2), 1-20.

Ulstad, S. O., Halvari, H., Sørebø, Ø., \& Deci, E. L. (2016). Motivation, Learning Strategies, and Performance in Physical Education at Secondary School. Advances in Physical Education, 6(01), 27.

Üredi, I., \& Üredi, L. (2005). İlköğretim 8. sinıf öğrencilerinin öz-düzenleme stratejileri ve motivasyonel inançlarının matematik başarısını yordama gücü. Mersin Üniversitesi Ĕ̆itim Fakültesi Dergisi, 1(2), 250-260.

Vural, L. (2012). Öğrenme stratejileri öğretiminin öğretmen adaylarinin strateji kullanimlarina etkisi. (Ph.D.), Anadolu Üniversitesi, Eskişehir.

Wahlheim, C. N., McDaniel, M. A., \& Little, J. L. (2016). Category learning strategies in younger and older adults: Rule abstraction and memorization. Psychology $\mathcal{E}$ Aging.

Weinstein, C. E., \& Mayer, R. E. (1983). The teaching of learning strategies. Paper presented at the Innovation abstracts.

Weinstein, C. E., \& Mayer, R. E. (1986). The teaching of learning strategies. In M. C. Wittrock (Ed.), Handbook of Research on Teaching (3rd ed., pp. 315-327). New York: Macmillan.

Wilson, A., \& Kim, W. (2016). The Effects of Concept Mapping and Academic Self-Efficacy on Mastery Goals and Reading Comprehension Achievement. International Education Studies, 9(3), 12.

Yılmaz, M., Gürçay, D., \& Ekici, G. (2007). Akademik özyeterlik ölçeğinin Türkçe'ye uyarlanması. Hacettepe Üniversitesi Ĕ̆itim Fakültesi Dergisi, 33, 253-259. 
Cumhuriyet International Journal of Education-CIJE

e-ISSN: $2147-1606$

Vol 5 (3), 2016, 48 - 66

Youngju, J., Jae-Eun, J., BoKyung, J., YooKyung, H., \& Se-Bin, C. (2007). Analysis of the relationship of students' self-efficacy, test anxiety, and parental involvement toward learning strategy and achievement in Korean middle school mathematics http://icome2013.iwd.jp/program/pdf/1p_PDF/A10.pdf

Zimmerman, B. J., Bandura, A., \& Martinez-Pons, M. (1992). Self-motivation for academic attainment: The role of self-efficacy beliefs and personal goal setting. American educational research journal, 29(3), 663-676. 